\title{
VARIATION OF PHYSICAL AND CHEMICAL PARAMETERS IN GROUNDWATER IN THE NORTHWESTERN PART OF THE DRINI I BARDHË RIVER BASIN, KOSOVO
}

\author{
Fisnik Laha ${ }^{1}$, Fatbardh Gashi", Hazir Çadraku \\ $13^{*} U B T$ - Higher Education Institution, Prishtina, Kosovo; \\ ${ }^{2}$ University of Prishtina "Hasan Prishtina", Faculty of Mathematics and Natural Sciences, \\ Department of Chemistry, Prishtina, Kosovo; \\ ${ }^{*}$ Correspondent author Fisnik Laha, e-mail: fisnik.laha@ubt-uni.net; \\ * fatbardh_gashi@hotmail.com; hazir.cadraku@ubt-uni.net;
}

"Received March 2019; Accepted April 2019; Published July 2019;

DOI: https://doi.org/10.31407/ijees9305

\begin{abstract}
Groundwater resources represent one of the safest sources of drinking water supply. In many parts of the world over $70 \%$ of drinking water is made up of groundwater. In the Republic of Kosovo, the supply of potable water from groundwater sources is represented by about $40 \%$. However, in the last few decades there is a growing concern about the quality of groundwater. Therefore, this paper through the scientific research, laboratory analysis and the obtained and interpreted results aims at highlighting the quality of groundwater in the northwestern area of the watershed of Drini i Bardhë (Kosova), through physicochemical indicators. On this occasion, 50 points for the physicochemical analysis of samples in groundwater were determined. Some of the physicochemical parameters are directly measured in the field, such as: temperature, $\mathrm{pH}$, electrical conductivity, dissolved oxygen in the water, etc., while other parameters are analyzed in the laboratory. Based on the results obtained through laboratory analysis, groundwater in this area shows results which are on the accepted limits in terms of quality properties. Those samples are within the allowed pirmisible values as defined by AI No. 16/2012 and WHO norms for drinkinig water. In some sample stations, there are some registered exceeded values for some chemical prarameters which are above the accpeted WHO limits for drinking water. The $\mathrm{CO}_{2}$ content shows that in this area the groundwaters are with atmospheric origin and the high value of kalium, calcium and nitate content, which were registered on two sample points could be explained from the overuse of of the agriculture fertilizers.
\end{abstract}

Keywords: Groundwater, Drini i Bardhë basin, physico-chemical, watershed area, variation. 